\title{
An Endangered Medicinal Plant, Ilex khasiana Exhibits Potent Antiparasitic Activity Against Intestinal Tapeworm
}

\author{
Charles Lalnunfela ${ }^{1,2}$, P. B. Lalthanpuii ${ }^{2}$, T. C. Lalhriatpuii ${ }^{1}$, K. Lalchhandama ${ }^{2, *}$
}

Charles Lalnunfela ${ }^{1,2}$, P. B.

Lalthanpuii ${ }^{2}$, T. C. Lalhriatpuii ${ }^{1}$, K. Lalchhandama ${ }^{2, *}$

'Department of Pharmacy, Regional Institute of Paramedical and Nursing Sciences, Zemabawk 796017, Mizoram, INDIA.

${ }^{2}$ Department of Life Sciences, Pachhunga University College, Aizawl 796001

Mizoram, INDIA.

\section{Correspondence}

\section{K. Lalchhandama}

Department of Life Sciences, Pachhunga

University College, Aizawl 796001

Mizoram, INDIA.

E-mail: chhandama@pucollege.edu.in

History

- Submission Date: 01-04-2020;

- Review completed: 16-04-2020;

- Accepted Date: 04-05-2020;

DOI : 10.5530/pj.2020.12.105

Article Available online

http://www.phcogj.com/v12/i4

Copyright

(C) 2020 Phcogj.Com. This is an openaccess article distributed under the terms of the Creative Commons Attribution 4.0 International license.

\section{ABSTRACT}

Background: A species of holly, llex khasiana Purk. (family Aquifoliaceae) is one of a few critically endangered medicinal plants in India. It is endemic to Khasi Hills, Meghalaya, and Aizawl, Mizoram. In the traditional medicines of Khasi and Mizo people, the leaves are used as a panacea for all sorts of infections. Nothing is known about its true pharmacological potentials. Objective: We aimed to assess the extract of $I$. Khasiana leaves for its purported antiparasitic property. To test the antiparasitic activity, we collected intestinal tapeworms, Raillietina tetragona. Materials and Methods: I. Khasiana leaves were dried and extracted in methanol. The plant extract was used to treat the tapeworms at different concentrations. The efficacy was recorded as survival values and were analysed by Student's $t$-test. The plant extracttreated tapeworms were fixed, dehydrated and observed under scanning electron microscopy for studying the structural details. Results: The methanol extract of $I$. khasiana leaf showed dose-dependent antiparasitic effect as that of albendazole. The treated tapeworms developed massive structural damages. The scolex was deformed, with its tegument extensively damaged. The suckers had their spines clumped. The body segments severely contracted and some portions were eroded. Hair-like microtriches were completely lost. Conclusion: Our findings indicate that $I$. Khasiana has antiparasitic activity and requires further investigations, and that there is a need to foster its conservation and propagation.

Key words: Medicinal plant, Parasite, Scanning electron microscopy, Tegument, Tapeworm.

\section{INTRODUCTION}

With almost 600 species described so far in the family Aquifoliaceae, Ilex is the only surviving genus. Commonly known as holly, species of Ilex are familiar in traditional Chinese medicine, especially I. kudingcha and I. latifolia, the leaves of which are parts of dietary foods. They are used as therapeutic agents for their analgesic, antidiarrhoeal, antipyretic, astringent, haematostatic, and hepatoprotective properties. ${ }^{1}$ South American natives use $I$. paraguariensis leaves as health-benefit drink and are now commercialised as mate tea. The drink is acclaimed for its hepatoprotection, digestive, antirheumatism, and anti-obesity properties, as well as its ability to prevent arthritis, inflammation, hypertension and hypercholesterolemia. ${ }^{2}$ Bioactive compounds from the plant are experimentally validated to have antiinflammatory, ${ }^{3}$ anticancer, ${ }^{4}$ anti-obesity, ${ }^{5}$ and cholesterol-reducing activities in animal models. ${ }^{6}$

I. pubescens is also well known in traditional Chinese medicine for the treatment of coronary heart diseases, and as antiinflammatory and analgesic agents. ${ }^{1}$ It is also known to be an effective remedy for hypertension, hyperlipemia, and hepatitis. ${ }^{7}$ Compounds from its root are demonstrated as having anticoagulant, ${ }^{8}$ antiinflammatory, ${ }^{9}$ and neuro-protective activities. ${ }^{10}$ I. cornuta is used in the treatment for dizziness and hypertension. ${ }^{11}$ Saponins from its roots are validated as possessing antiviral activity against herpes simplex virus type $1,{ }^{12}$ and myocardial (heart tissue) damage inhibition. ${ }^{13}$ I. ficoidea and I. centrochinensis were shown to have potent antiinflammatory and antioxidant activities. ${ }^{14}$

Out of 410 accepted species recorded in the genus Ilex, I. khasiana Purk. is outstanding in that it is critically endangered according to the IUCN Red List of Threatened Species, ${ }^{15}$ and that its cohort of medicinal properties attracts the least interest so far. It is reported as endemic to the Khasi Hills of Meghalaya, northeast India. About 3,000 individual trees are estimated to exist in these areas. ${ }^{16} \mathrm{But}$ an isolated distribution is also now recorded at Luangmual, Aizawl, Mizoram. Among the Khasi people, a decoction of the bark and the root is used in the treatment of tuberculosis and severe cold. ${ }^{17}$ The leaves are known for various medicinal properties including antiparasitic property in Mizo traditional medicine. In fact, the Mizo traditional practitioners use them as a panacea in all sorts of non-specific illnesses. ${ }^{18}$ It is therefore important to understand the true pharmacological potentials of this plant as an antiparasitic agent.

\section{MATERIALS AND METHODS}

Plant specimen and preparation of plant extract

Ilex khasiana is available only at one area in Mizoram, India, as naturally propagated tree at Luangmual, Aizawl (location $23^{\circ} 44.556^{\prime} \mathrm{N}$ and $92^{\circ} 41.956^{\prime} \mathrm{E}$ ). The plant specimen was authenticated at the Botanical Survey of India, Eastern Circle, Shillong, Meghalaya 
as reported earlier. ${ }^{18}$ The herbarium is catalogued with an accession number BSI/EC/Tech./2008/577 in the Department of Pharmacy, Regional Institute of Paramedical and Nursing Sciences, Zemabawk, Mizoram, India.

The leaves were washed and dried under the shade at an ambient temperature $\left(23-25^{\circ} \mathrm{C}\right)$. The dry leaves were ground to a fine powder. Hot extraction was done using methanol as a solvent in a 5-litre Soxhlet apparatus for 72 hours. The crude extract was concentrated by evaporating and recovering the solvent in a rotary vacuum evaporator (Buchi Rotavapor R-215).

\section{In vitro survival test}

Antiparasitic activity was tested in vitro on the survival of the parasitic tapeworm Raillietina tetragona Molin, 1858. Live tapeworms were recovered from the intestines of freshly sacrificed local fowls, Gallus gallus Linnaeus, 1758. An hour before the test, the plant extract was prepared in increasing concentrations, i.e. $0.5,1,2,5,10$ and $20 \mathrm{mg} / \mathrm{ml}$ in culture plates by dissolving them in $0.9 \%$ neutral phosphate-buffered saline (PBS) supplemented with $1 \%$ dimethylsulfoxide (DMSO). Corresponding concentrations of albendazole were also prepared as standard references. Albendazole (Zenlee) was a product of UNI-PEX Pharmaceutical Private Limited, New Delhi, India.

Control media consisted only of PBS with DMSO. Batches of two worms were tested for each concentration, and each test was further performed in triplicates. The parasites were incubated at a constant temperature of $37 \pm 1^{\circ} \mathrm{C}$. Antiparasitic efficacy was assessed in terms of survival in the culture media. Death was defined as complete absence of motor activity even after physical provocation in lukewarm PBS $\left(45^{\circ} \mathrm{C}\right)$. The duration of survival was recorded, and data were generated as statistical means \pm standard deviation. Significance of the antiparasitic activity was determined using Student's $t$-test, and a $p$ value less than 0.05 was considered as significantly different.

\section{Scanning electron microscopy}

Tapeworms treated with the highest concentration, i.e. $20 \mathrm{mg} / \mathrm{ml}$ of the plant extract were chosen for scanning electron microscopy. After confirmation of death, they were immediately fixed in $4 \%$ formaldehyde, buffered with sodium cacodylate $(0.1 \mathrm{M}, \mathrm{pH} 7.2)$, at $4^{\circ} \mathrm{C}$ for 4 hours. Another fixation was done in $1 \%$ osmium tetroxide at $4^{\circ} \mathrm{C}$ for 1 hour. After 1 hour, the specimens were dehydrated through ascending grades of acetone up to pure acetone. They were then treated with tetramethylsilane for at least 15 minutes. The TMS was dried in an air-drying chamber maintained at $25^{\circ} \mathrm{C}$. The dried specimens were mounted on metal stubs, and then sputter coated with gold in an ionsputtering chamber (JFC 1100, JEOL Ltd., Tokyo, Japan). Finally, they were visualised under a scanning electron microscope (JSM-6360, JEOL Ltd., Tokyo, Japan) under an electron accelerating voltage of $20 \mathrm{kV}$.

\section{RESULTS}

The antiparasitic activity of the methanol extract of $I$. khasiana leaves and albendazole on the tapeworm, Raillietina tetragona, is given in Table 1 and Figure 1. Tapeworms in the control (negative treatment) media could survive up to $74.03 \mathrm{hr}$. Survival values were normalised against that of the control. At the concentrations of 1.25, 2.5, 5, 10 and $20 \mathrm{mg} / \mathrm{ml}$, the plant extract took $56.42 \pm 1.73,46.72 \pm 2.01,37.08 \pm 1.98$, $29.25 \pm 1.76$, and $20.40 \pm 2.55 \mathrm{~h}$ to kill all the parasites. Whereas the drug albendazole took $23.76 \pm 1.93,20.24 \pm 0.58,16.30 \pm 0.66,12.15 \pm$ 0.61 , and $4.39 \pm 0.88 \mathrm{hr}$ respectively for killing the tapeworms.

Scanning electron microscopy revealed details of structural changes on the tapeworms treated with $20 \mathrm{mg} / \mathrm{ml}$ of $I$. khasiana leaf extract. Figure 2 is the anterior part of the tapeworm consisting of the bulb-like scolex and the adjoining neck. Large folds were visible at the base of the scolex and on the neck showing tegumental degeneration at the anterior end of the body. A single sucker shown in Figure 3 indicates tegumental shrinkage and disintegration of the spines around the rim. A magnified view of the same sucker (Figure 4) revealed disordered and clumping of the spines and debris-like tegumental erosion.

The main body (strobila) of tapeworms is a series of body segments (proglottids). All the body segments exhibited irregular shrinkage and appeared to undergo severe contractions (Figure 5). Some portions were sloughed off. A close-up view of one body segment showed that

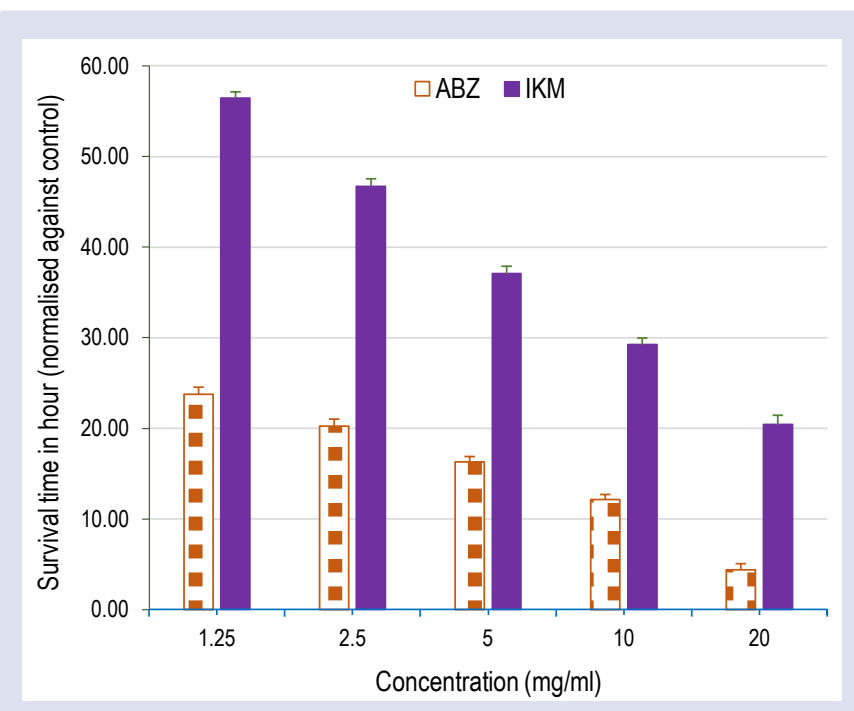

Figure 1: Graph showing the concentration-dependent activity of albendazole (ABZ) and the methanol extract of I. khasiana leaf (IKM) against $R$. tetragona.

Table 1: Antiparasitic activity of $\boldsymbol{l}$. khasiana leaf extract and albendazole on $\boldsymbol{R}$. tetragona.

\begin{tabular}{|c|c|c|c|c|}
\hline Media & Dose $(\mathrm{mg} / \mathrm{ml})$ & Normalised survival time in $\mathrm{hr}( \pm \mathrm{SD})$ & $\mathrm{t}$ value & $\mathrm{t}$ critical value \\
\hline Control & 0 & $100.00 \pm 2.56$ & - & - \\
\hline \multirow[t]{6}{*}{ Albendazole } & 1.25 & $023.76 \pm 1.93$ & 58.32 & $2.26^{*}$ \\
\hline & 2.5 & $020.24 \pm 0.58$ & 74.53 & $2.45^{*}$ \\
\hline & 5 & $016.30 \pm 0.66$ & 77.66 & $2.45^{*}$ \\
\hline & 10 & $012.15 \pm 0.61$ & 81.85 & $2.45^{*}$ \\
\hline & 20 & $004.39 \pm 0.88$ & 86.57 & $2.45^{*}$ \\
\hline & 1.25 & $056.42 \pm 1.73$ & 34.57 & $2.26^{*}$ \\
\hline \multirow[t]{4}{*}{ I. khasiana leaf extract } & 2.5 & $046.72 \pm 2.01$ & 40.14 & $2.26^{*}$ \\
\hline & 5 & $037.08 \pm 1.98$ & 47.62 & $2.26^{*}$ \\
\hline & 10 & $029.25 \pm 1.76$ & 55.78 & $2.26^{*}$ \\
\hline & 20 & $020.40 \pm 2.55$ & 53.96 & $2.23^{*}$ \\
\hline
\end{tabular}

*Significantly different at $p<0.05$ in comparison with control (negative treatment) group; $n=6$. 
the surface is full of tanged fibres, indicating destruction of hair-like microtriches (Figure 6). The severity of the tegumental shrinkage is more clearly discernible with transverse rows of grooves and ridges.

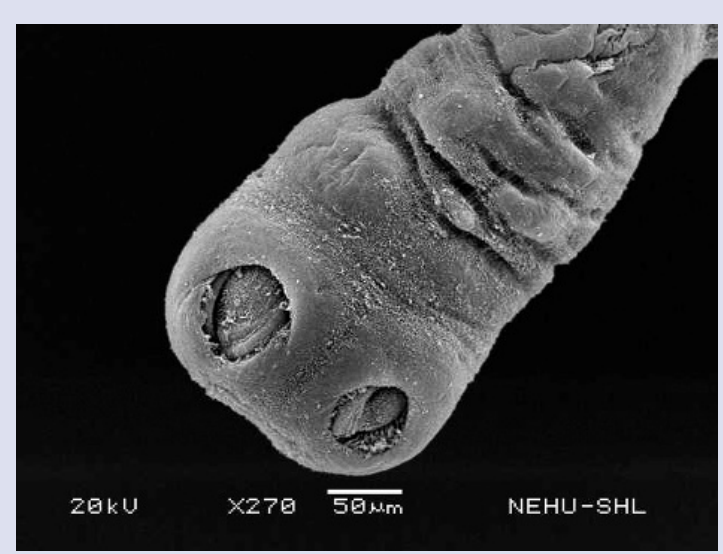

Figure 2: Scanning electron microscopy of R. tetragona treated with the methanol extract of $I$. khasiana leaf. Anterior portion of the tapeworm consists of bulbous scolex and the connecting neck. Two hole-like suckers are visible. Large folds are present at the base of the scolex and on the neck.

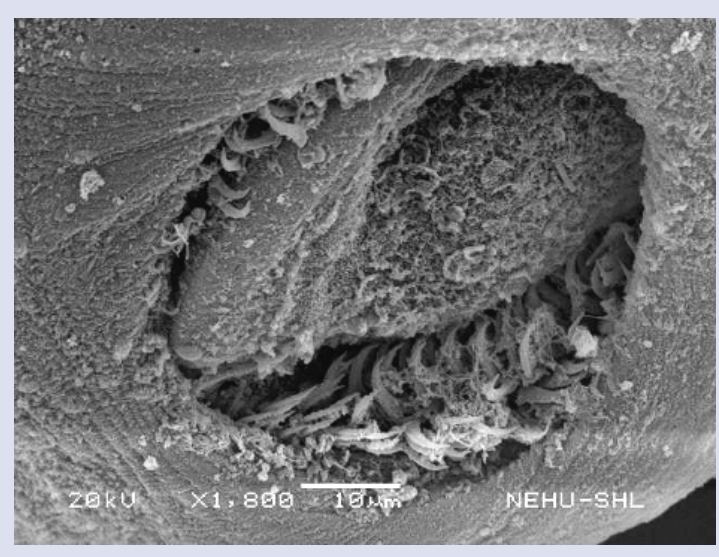

Figure 3: Magnification of the lower part of R. tetragona scolex showing a single sucker. The pointed spines on the rim are disintegrating, some on the upper rim are almost dislodged. The surrounding tegument is with numerous wrinkles.

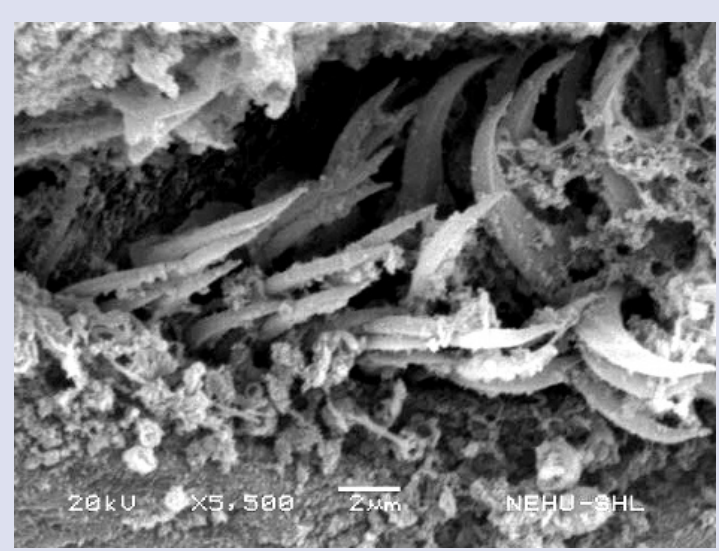

Figure 4: A portion of the sucker of $R$. tetragona showing irregularly oriented spines surrounded by debris of tegumental surface, indicating degenerated microtriches.

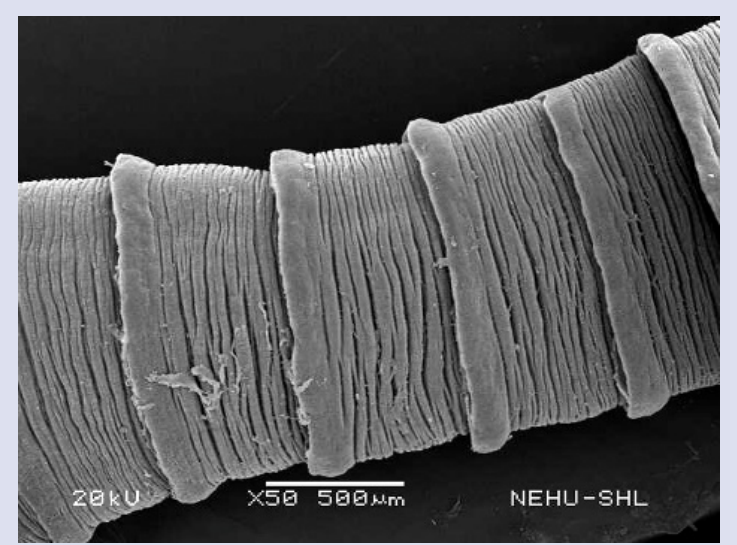

Figure 5: The main body of $R$. tetragona showing a series of body segments (proglottid). All of them are severely contracted. A portion of the lower-left region reveals surface erosion.

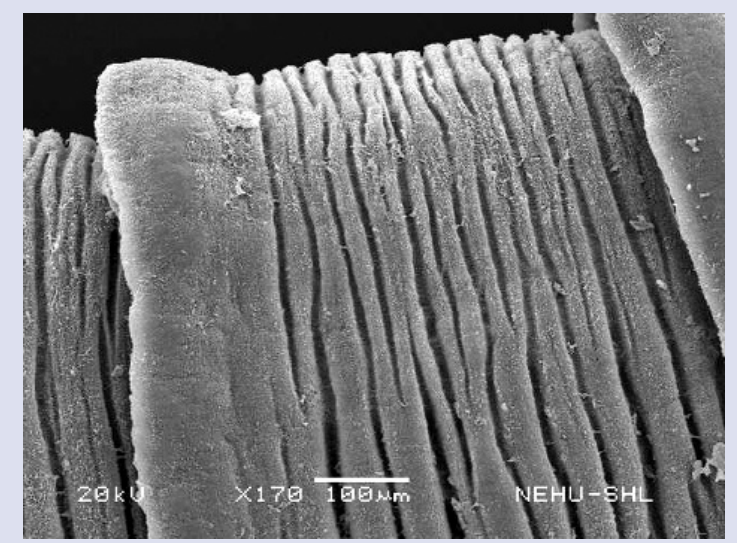

Figure 6: A single body segment of $R$. tetragona revealing damaged tegument. The mess of fibres are degenerated microtriches.

\section{DISCUSSION}

Tapeworms are a group of helminth parasites which are largely ignored and often described as "low priority" infectious agents due to their relative quiescence in most infections. However, they pose serious threats to clinical conditions such as neurocysticersosis in humans, ${ }^{19}$ livestock production, ${ }^{20}$ and wildlife. ${ }^{21}$ They are distinct helminths in having rather modest anatomical organisation; lack of nervous and digestive systems being the unique features. Their external body surface called tegument is the principal body organ as it serves not only as a protective barrier, but also as nutrient-absorptive and sensory site. ${ }^{22}$ These functions are carried out through microscopic hairs called microtriches, which are distributed throughout the tegument. Thus, the hallmark effects of antiparasitic drugs are structural damages on the tegument, microtriches and the underlying subtegument tissue..$^{23,24}$

The detail structural features of the tegument and its physical and physiological roles in poultry tapeworms are already amply described. ${ }^{25,26}$ In our experiment, the methanol extract of $I$. khasiana leaves caused considerable tegumental damages including shrinkage, distortion of the spines and rostellum, and erosion of the microtriches. The antiparasitic activity was further substantiated by concentrationdependent lethal activity on $R$. tetragona similar to that of albendazole.

Benzimidazoles are the drugs of choice in all types of helminth infection because of their broad-spectrum activity. The most commonly used 
benzimidazoles, albendazole and flubendazole cause degeneration of the rostellum, destruction of the microtriches, and eruption of aberrant vesicles on the human tapeworm, Echinococcus granulosus. ${ }^{27}$ A combination therapy of albendazole and praziquantel resulted in disintegration of the suckers, detachment of the spines, and severe damage of the tegument, associated with removal of the microtriches in E. granulosus and Mesocestoides corti. ${ }^{28,29} \mathrm{~A}$ single treatment of $R$. echinobothrida with albendazole produced severe tegumental contraction and collapse. In addition, the suckers were destroyed while the rostellum remained intact. ${ }^{30}$

Nitazoxanide also induced pore formation on the scolex and distortion of the neck and the strobilar chains of the immature (cysticerci) of Taenia solium. ${ }^{31}$ E. granulosus and E. multiclocularis treated with lonidamine and 6-aminonicotinamide showed tegumental darkening, swelling and shortening of the body segments, surface erosion, and severe damages of the rostellum and suckers. ${ }^{32}$ It is also apparent that in spite of the common structural damages they induce, each drug exhibit variation in its effect on the intensity and extend of tegumental alterations. We observed that $I$. khasiana leaf extract indiscriminately acted on the entire body parts of $R$. tetragona. The clumping of spines and extensive contraction of the body segments appear to be unique. Our findings indicate that the plant extract has different mode of action and open a new vista for the development of novel antiparasitic drug.

\section{CONCLUSION}

We found that I. khasiana leaf extract effectively killed the tapeworm $R$. tetragona. It caused structural damages on the tegument of the tapeworm, indicating the characteristic antiparasitic effects. Under scanning electron microscopy, distortion of the microtriches, clumping of the spines, erosion of the microtriches and extensive contraction of the tegument were evident. The need for conservation and propagation of this valuable medicinal plant is compelling. Further studies on the chemical components of the medicinal plant, isolation of the active principle, and mode of action of the compound are warranted by our findings.

\section{CONFLICTS OF INTEREST}

None declared.

\section{ACKNOWLEDGEMENT}

Scanning electron facility was provided by the Sophisticated Analytical Instrument Facility (SAIF), North Eastern Hill University, Meghalaya, India.

\section{REFERENCES}

1. Hao D, Gu X, Xiao P, Liang Z, Xu L, Peng Y. Research progress in the phytochemistry and biology of llex pharmaceutical resources. Acta Pharmaceutica Sinica B. 2013;3(1):8-19.

2. Junior EL, Morand C. Interest of mate (/lex paraguariensis A. St.-Hil.) as a new natural functional food to preserve human cardiovascular health - A review. Journal of Functional Foods. 2016;21:440-54

3. Puangpraphant S, de Mejia EG. Saponins in yerba mate tea (/lex paraguariensis A. St.-Hil) and quercetin synergistically inhibit iNOS and COX-2 in lipopolysaccharide-induced macrophages through NF $\kappa$ B pathways. Journal of Agricultural and Food Chemistry. 2009;57(19):8873-83.

4. de Mejía EG, Song YS, Heck Cl, Ramírez-Mares M. Yerba mate tea (/lex paraguariensis): Phenolics, antioxidant capacity and in vitro inhibition of colon cancer cell proliferation. Journal of Functional Foods. 2010;2(1):23-34.

5. Hussein GM, Matsuda H, Nakamura S, Hamao M, Akiyama T, Tamura K, Yoshikawa M. Mate tea (/lex paraguariensis) promotes satiety and body weight lowering in mice: involvement of glucagon-like peptide-1. Biological and Pharmaceutical Bulletin. 2011;34(12):1849-55.

6. Klein GA, Stefanuto A, Boaventura BC, De Morais EC, Cavalcante LD, De Andrade $F$, et al. Mate tea (Ilex paraguariensis) improves glycemic and lipid profiles of type 2 diabetes and pre-diabetes individuals: a pilot study. Journal of the American College of Nutrition. 2011;30(5):320-32.

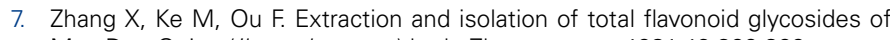
Mao Don Quing (Ilex pubescens) bark. Zhongcaoyao. 1981;12:399-399.

8. Tan Q, Qiu M, Cao D, Xiong T, Zhang L, Zhou L, et al. Triterpenoids with antiplatelet aggregation activity from the roots of Ilex pubescens. Planta Medica. 2017;83(9):797-804.

9. Wu P, Gao H, Liu JX, Liu L, Zhou H, Liu ZQ. Triterpenoid saponins with anti-inflammatory activities from Ilex pubescens roots. Phytochemistry. 2017; 134:122-32

10. Fang $X$, Li Y, Qiao J, Guo Y, Miao M. Neuroprotective effect of total flavonoids from Ilex pubescens against focal cerebral ischemia/reperfusion injury in rats. Molecular medicine reports. 2017;16(5):7439-49.

11. Wenjuan $Q$, Xiue W, Junjie Z, Fukuyama Y, Yamada T, Nakagawa K. Triterpenoid glycosides from leaves of Ilex cornuta. Phytochemistry. 1986;25:913-6.

12. Zhou M, Xu M, Ma XX, Zheng K, Yang K, Yang CR, et al. Antiviral triterpenoid saponins from the roots of Ilex asprella. Planta Medica. 2012;78(15):1702-5.

13. Wang W, Zhao J, Li S, LuY, Liu Y, Xu Q, et al. Five new triterpenoidal saponins from the roots of Ilex cornuta and their protective effects against $\mathrm{H} 2 \mathrm{O} 2$-induced cardiomyocytes injury. Fitoterapia. 2014;99(1):40-7.

14. Li L, Zhang Y, Zhang P, Pi H, Ruan H, Wu J. Appraisal of anti-inflammatory and free radical scavenging activities of ethanol extract of Ilex ficoidea Hems and Ilex centrochinensis SY Hu. Environmental Toxicology and Pharmacology 2011;32(2):122-7.

15. Krishna U, Kanta BS, Dibyendu A, Ratul B, John LN. Regeneration ecology and population status of a critically endangered and endemic tree species (/lex khasiana Purk.) in north-eastern India. Journal of Forestry Research. 2009;20(3):223-8.

16. Adhikari D, Barik SK, Upadhaya K. Habitat distribution modelling for reintroduction of Ilex khasiana Purk., a critically endangered tree species of northeastern India. Ecological Engineering. 2012;40(1):37-43.

17. Laloo RC, Kharlukhi L, Jeeva S, Mishra BP. Status of medicinal plants in the disturbed and the undisturbed sacred forests of Meghalaya, northeast India: population structure and regeneration efficacy of some important species. Current Science. 2006;90(2):225-32.

18. Lalnunfela C, Lalremsanga $H T$, Lalhriatpuii TC, Lalnunzira D, Lalchhandama $\mathrm{K}$. Unveiling the unexplored and critically endangered Ilex khasiana for its antioxidant properties. Journal of Natural Remedies. 2019;19(4):139-45.

19. Gripper LB, Welburn SC. Neurocysticercosis infection and disease - A review. Acta Tropica. 2017;166:218-24.

20. Brožová $A$, Jankovská I, Bejček $V$, Nechybová $S$, Peřinková $P$, Horáková $B$, et al. Echinococcus spp.: Tapeworms that pose a danger to both animals and humans-a review. Scientia Agriculturae Bohemica. 2017;48(4):193-201.

21. Griffin RH, Gomery MA, Dorny $P$, Noh JC, Handali S, Chastain HM, et al. Identifying wildlife reservoirs of neglected taeniid tapeworms: Non-invasive diagnosis of endemic Taenia serialis infection in a wild primate population. PLoS Neglected Tropical Diseases. 2017;11:e0005709.

22. Rana AK, Misra-Bhattacharya S. Current drug targets for helminthic diseases. Parasitology Research. 2013;112(5):1819-31.

23. Taman A, Azab M. Present-day anthelmintics and perspectives on future new targets. Parasitology Research. 2014;113(7):2425-2433.

24. Roy B, Lalchhandama K, Dutta B. Scanning electron microscopic observations on the in vitro anthelmintic effects of Millettia pachycarpa on Raillietina echinobothrida. Pharmacognosy Magazine. 2008;4(13):20-6.

25. Bâ CT, Sene T, Marchand B. Scanning electron microscope examination of scalelike spines on the rostellumm of five Davaineinae (Cestoda, Cyclophyllidea). Parasite. 1995;2(1):63-7.

26. Lalchhandama K. On the structure of Raillietina echinobothrida, the tapeworm of domestic fowl. Science Vision. 2009;4:174-82.

27. Elissondo M, Dopchiz M, Ceballos L, Alvarez L, Bruni SS, Lanusse C, Denegri G. In vitro effects of flubendazole on Echinococcus granulosus protoscoleces. Parasitology Research. 2006;98(4):317-23.

28. Urrea-Paris MA, Moreno MJ, Casado N, Rodriguez-Caabeiro F. In vitro effect of praziquantel and albendazole combination therapy on the larval stage of Echinococcus granulosus. Parasitology Research. 2000;86(12):957-64.

29. Markoski MM, Trindade ES, Cabrera G, Laschuk A, Galanti N, Zaha A, et al. Praziquantel and albendazole damaging action on in vitro developing Mesocestoides corti (Platyhelminthes: Cestoda). Parasitology International. 2006;55(1):51-61.

30. Lalchhandama K. In vitro effects of albendazole on Raillietina echinobothrida the cestode of chicken, Gallus domesticus. Journal of Young Pharmacists. 2010;2(4):374-8

31. Ambrosio JR, Ferrer A, Zepeda-Rodriguez A. In vitro effects of nitazoxanide on the morphology of nascent and immature adult stages of Taenia solium. Annals of Clinical Pathology. 2017;5(4):1117(1-9).

32. Xin $\mathrm{Q}$, Yuan $\mathrm{M}$, Li H, Song $\mathrm{X}$, Lu J, Jing $\mathrm{T}$. In vitro effects of lonidamine and 6-aminonicotinamide against Echinococcus granulosus sensu stricto and Echinococcus multilocularis. Veterinary Research. 2020;51(1):1-7. 


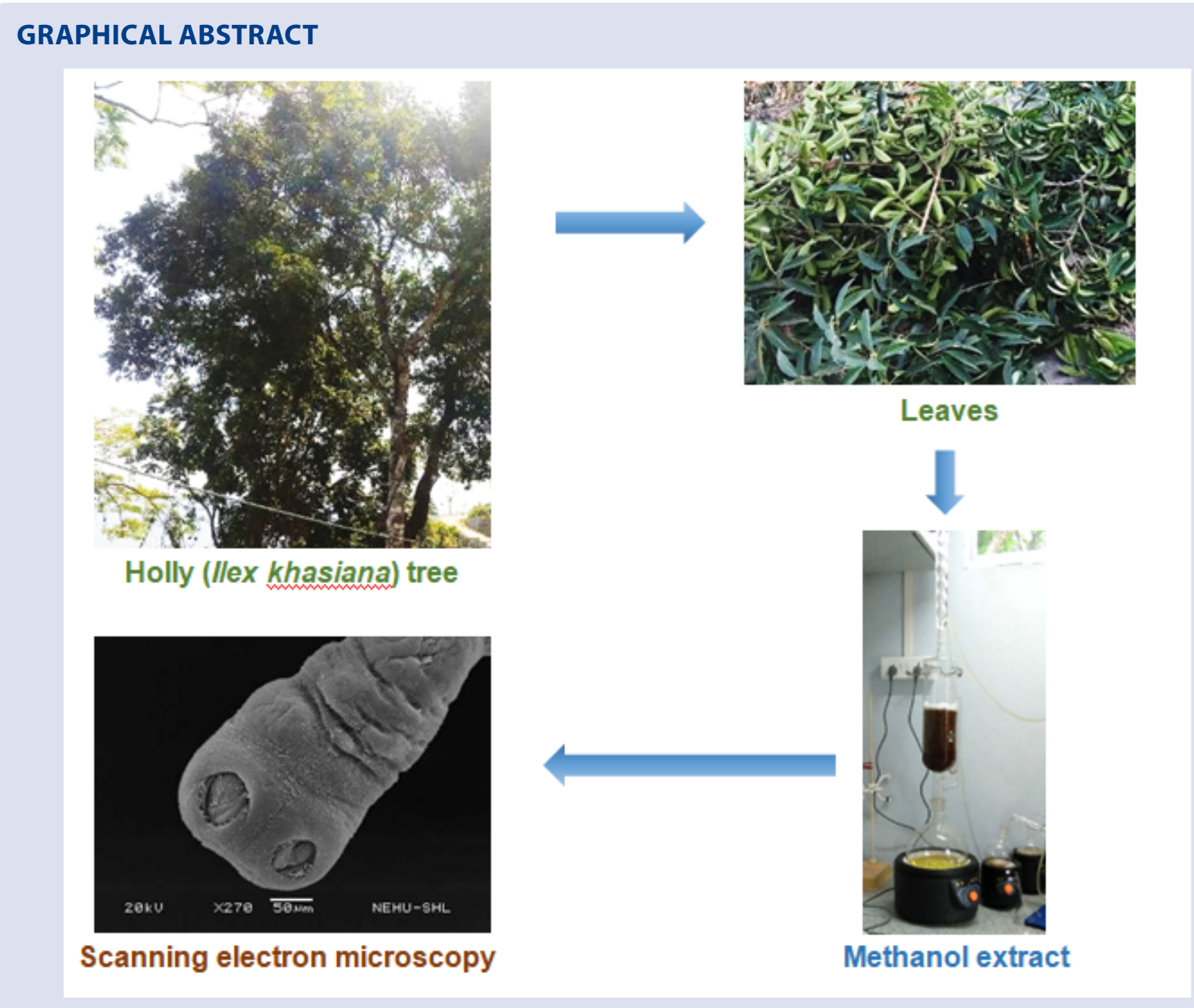

\section{SUMMARY}

- A species of holly, Ilex khasiana, is a critically endangered medicinal plants that is known to have a variety of uses in traditional medicine. Among its medicinal properties is antiparasitic activity.

- The methanol extract of the leaves was tested in vitro against an intestinal tapeworm, Raillietina tetragona. The plant extract caused dose-dependent antiparasitic activity against the tapeworm as that of albendazole.

- Scanning electron microscopy was used to examine structural changes on the tapeworm. The body surface (tegument) indicated damages which are characteristics of antiparasitic drugs such as shrinkage, erosion, disintegration of the suckers, and removal of microtriches.

- The damaging effects imply that the plant possesses bioactive compounds that can be new lead molecules in drug development. Thus, the findings warrant further investigations on the chemical nature and precise mode of action.

\section{ABOUT AUTHORS}

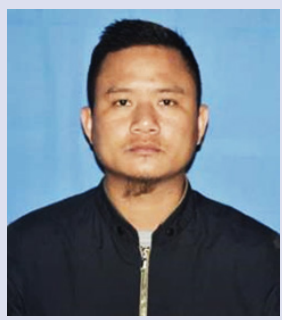

Charles Lalnunfela: $\mathrm{He}$ is a graduate in Genetics from the University of Madras and a PhD scholar at the Department of Pharmacy, Regional Institute of Paramedical and Nursing Sciences, Zemabawk, Mizoram, India. 

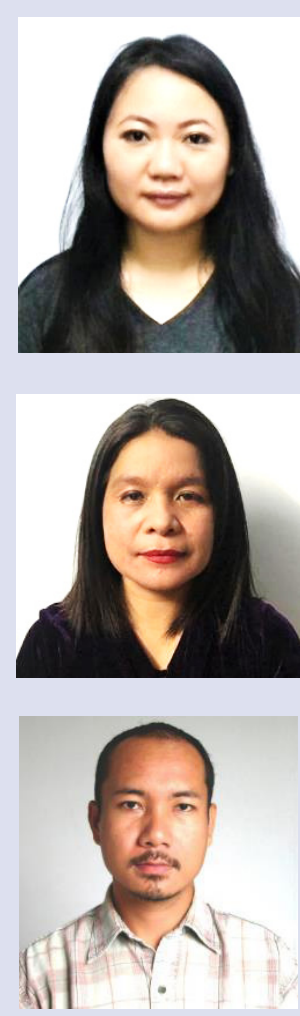

P. B. Lalthanpuii: She is a graduate in zoology from North Eastern Hill University and is currently a Senior Research Fellow in the Department of Life Sciences at Pachhunga University College, Aizawl, Mizoram, India.

T. C. Lalhriatpuii: She is a graduate in pharmacy and completed her doctoral research from the Dibrugarh University. She is serving as an Assistant Professor at the Department of Pharmacy, Regional Institute of Paramedical and Nursing Sciences, Zemabawk 796017, Mizoram, India.

Kholhring Lalchhandama: He graduated in zoology from North Eastern Hill University and earned his doctorate from Assam University. He is currently an Associate Professor and Head of the Department of Life Sciences, Mizoram University, at Pachhunga University College, Aizawl, India.

Cite this article: Lalnunfela C, Lalthanpuii PB, Lalhriatpuii TC, Lalchhandama K. An Endangered Medicinal Plant, /lex Khasiana Exhibits Potent Antiparasitic Activity Against Intestinal Tapeworm. Pharmacogn J. 2020;12(4):725-30. 